\title{
On the Female Sex Pheromones and Courtship Behaviour in the Bitterlings Rhodeus ocellatus ocellatus and Acheilognathus lanceolatus
}

\author{
Haruo HoNDA* \\ (Received July 8, 1981)
}

\begin{abstract}
It was demonstrated that males of rose bitterling Rhodeus ocellatus ocellatus were able to discriminate post-ovulatory females from pre-ovulatory ones on the basis of a chemical cue. And also males of slender bitterling Acheilognathus lanceolatus were able to discriminate between postovulatory females and pre-ovulatory ones on the basis of a chemical cue. Some important aspects derived from the experiments are listed as follows;

1. Post-ovulatory females of each species released a female sex pheromone respectively, which males detect by olfaction.

2. The pheromone of each species was present in the genital cavity fluid and in the ovaries of post-ovulatory females.

3. Males of each species discriminated post-ovulatory females of their own kind from those of other species by olfaction. And difference of female sex pheromone was observed between the two bitterlings.
\end{abstract}

Female of bitterlings has a ovipositor and lays her eggs in the gill cavity of freshwater mussel. AsAHINA and others ${ }^{13}$ reported that post-ovulatory females of rose bitterling (Japanese name: tairikubaratanago) Rhodeus ocellatus ocellatus had longer ovipositor than pre-ovulatory ones. And WIEPKEMA ${ }^{27}$ reported that females of an European bitterling $R$. amarus having long ovipositor were ready to spawn. These reports raised a intriguing question of whether or not long ovipositor of post-ovulatory female plays a role informing males of the occurrence of ovulation in females as a visual cue, since the author demonstrated that female sex pheromones were used as a chemical cue informing males of the occurrence of ovulation in three species of fish. ${ }^{3-\delta)}$

This study was designed to explore the cue informing males of the occurence of ovulation in rose bitterling and slender bitterling (Japanese name: yaritanago) Acheilognathus lanceolatus.

\section{Materials and Methods}

Fish

Rose bitterling, ranging from 37 to $68 \mathrm{~mm}$ in standard length, were collected with a trap in the Tone River in Abiko City in April 1980. Slender bitterling, ranging from 58 to $76 \mathrm{~mm}$ in standard length, were obtained from a local dealer in Abiko City in April 1980. The fish of each species were reared separately according to species and sex at $20-23^{\circ} \mathrm{C}$ until used in experiments.

\section{Courtship Tests}

A plastic aquarium $(60 \times 30 \times 35 \mathrm{~cm})$ equipped with an air-stone was used. The floor of aquarium was covered with sand and a freshwater mussel Anadonta woodiana was settled at center of the floor. Thirty min after placing a male in the aquarium, either a post-ovulatory female or a preovulatory one was put into the aquarium and courtship behaviour of the male was observed for $30 \mathrm{~min}$.

\section{$Y$-maze Tests}

Preference tests were carried out using a $\mathrm{Y}$ maze as shown in Fig. 1. A pair of stimulus sources (Table 1) was pumped at a rate of $2 l$ per min into the two upper stream arms of the maze from two $150 l$ reservoirs. Five min after placing a male in the starting gate, the gate was opened and the male was given $10 \mathrm{~min}$ to choose between two upper stream arms of the maze. When the male made a response by entering an upper stream arm of the maze, or if no response was made within $10 \mathrm{~min}$, the test for the male was stopped. After

* Bio-Environment Laboratory, Central Research Institute of Electric Power Industry, Abiko, Chiba 27011, Japan (本田晴朗: 電力中央研究所，生物環境技街研究所). 


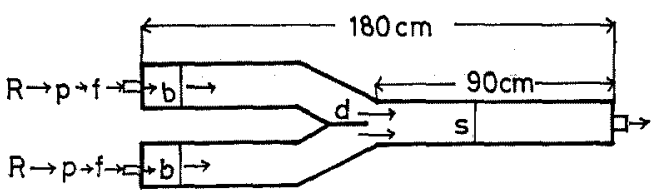

Fig. 1. Plane figure of Y-maze device. $\mathbb{R}: 150 \mathrm{l}$ reservoir. P: pump. f: flow meter. b: baffe plate. d: divider. s: starting gate (movable screen). Arrows: stream direction. Width: $15 \mathrm{~cm}$. Depth: $15 \mathrm{~cm}$. Distance from starting gate to choice point: $40 \mathrm{~cm}$.

Table 1. Pairs of stimulus sources used in the $\mathrm{Y}$-maze tests

\begin{tabular}{cll}
\hline \multirow{2}{*}{$\begin{array}{c}\text { Species of } \\
\text { males tested }\end{array}$} & \multicolumn{1}{c}{ A pair of stimulus sources } \\
\cline { 2 - 3 } Rose bitterling & \multicolumn{1}{c}{ A } & \multicolumn{1}{c}{ Post-ov(R) } \\
& $\begin{array}{l}\text { Egg washings(R) } \\
\text { Washed eggs (R) }\end{array}$ & $\begin{array}{l}\text { Pre-ov(R) } \\
\text { Ovary(R) } \\
\end{array}$ \\
& Post-ov(R) & Post-ov(S) \\
& Pre-ov(R) & Pre-ov(S) \\
\hline Slender & Post-ov(S) & Pre-ov(S) \\
bitterling & Egg washings(S) & Washed eggs(S) \\
& Washed eggs(S) & Ovary(S) \\
& Post-ov(S) & Post-ov(R) \\
& Pre-ov(S) & Pre-ov(R) \\
\hline
\end{tabular}

Post-ov: A post-ovulatory female was held in a reservoir during the test.

Pre-ov: A pre-ovulatory female was held in a reservoir. Egg washings: Obtained by washing $\mathrm{ca} .2 \mathrm{~g}$ of ovulated eggs with $50 \mathrm{ml}$ of water and filtering with gauze, then added into $150 /$ of water in a reservoir. Washed eggs: About $2 \mathrm{~g}$ of washed eggs were homogenized and added into $150 \mathrm{l}$ of water.

Ovary: About $2 \mathrm{~g}$ of ovaries of post-ovulatory females were homogenized and added into $150 \mathrm{l}$ of water.

(R): Rose bittering. (S): Slender bitterling.

a series of tests with 15 males, the position of each stimulus source in the maze was interchanged and another 15 males were tested. Thus, 30 males were tested with a pair of stimulus sources.

All experiments were carried out from April to July in 1980 during the spawning season of both species. Water temperature was maintained at $20-24^{\circ} \mathrm{C}$ through the experiments.

\section{Results and Discussion}

\section{Courtship Tests}

Courtship response of males of each species to post-ovulatory female or pre-ovulatory one of their own kind is shown in Table 2. Courtship behaviour of male was elicited in the case of placing a post-ovulatory female into the aquarium con-
Table 2. Courtship response of males

\begin{tabular}{llcc}
\hline Species & Female & $\begin{array}{c}\text { No. of } \\
\text { males } \\
\text { responded }\end{array}$ \\
\hline Rose bitterling & Post-ovulatory & 8 & 3 \\
& Pre-ovulatory & 0 & 8 \\
\hline Slender bitterling & Post-ovulatory & 5 & 1 \\
& Pre-ovulatory & 0 & 5 \\
\hline+ +: observed courtship. - : observed no courtship. &
\end{tabular}

taining a male. And any of the males tested never made territorial behaviour ${ }^{2,6,7)}$ to post-ovulatory females. On the other hand, to pre-ovulatory females, the males did not court and sometimes made territorial behaviour. Courtship behaviour of male of both species was very similar to each other. Although a few males did not court to the post-ovulatory female, within a few $\min$ after placement of a post-ovulatory female the male held in the aquarium exploded into courtship, beginning to lead the female to the mussel and quivered his body in front of the female. This quivering behaviour of male was never elicited by placing a post-ovulatory female placed in a rubber plugged transparent plastic pipe into the aquarium in both species. These results indicate that post-ovulatory females of each species might release a chemical communicant respectively.

\section{$Y$-maze Tests}

The response of males of each species to postovulatory female or pre-ovulatory one of their own kind in the $Y$-maze is shown in Table 3. The males of each species discriminated between postovulatory female and pre-ovulatory one without actually sighting the females. On the other hand, anosmic males, plugged their nostrils with an adhesive agent (Aron-Alpha), were not able to discriminate between post-ovulatory female and preovulatory one in both species as shown in Table 4. It became evident that post-ovulatory females of each species release respectively a sex pheromone attracting males and informing males of the occurrence of ovulation in females. And males of each species receive their pheromone by olfaction.

The response of males of each species to stimulus sourecs prepared by using ovulated eggs and ovaries from post-ovulatory females of their own kind (Table 1) is shown in Table 5. The males of both species preferred egg washings and homogenized ovaries to homogenized washed eggs. 
Table 3. Response of males to the females in the Y-maze

\begin{tabular}{llcc}
\hline Species & $\begin{array}{c}\text { Female as a } \\
\text { stimulus } \\
\text { source }\end{array}$ & $\begin{array}{c}\text { No. of } \\
\text { males } \\
\text { responded }\end{array}$ & $\chi^{2}$-test \\
\hline $\begin{array}{c}\text { Rose } \\
\text { bitterling }\end{array}$ & $\begin{array}{l}\text { Post-ovulatory } \\
\text { Pre-ovulatory }\end{array}$ & 22 & $p<0.001$ \\
\hline $\begin{array}{l}\text { Slender } \\
\text { bitterling }\end{array}$ & Post-ovulatory & 22 & $p<0.01$ \\
\hline $\begin{array}{c}\text { Each thirty males were tested. Some males did not respond } \\
\text { within 10 min. }\end{array}$ &
\end{tabular}

Table 4. Response of anosmic males to the females in the $Y$-maze

\begin{tabular}{clc}
\hline \multicolumn{1}{c}{ Species } & $\begin{array}{c}\text { Female as a } \\
\text { stimulus source }\end{array}$ & $\begin{array}{c}\text { No. of males } \\
\text { responded }\end{array}$ \\
\hline Rose bitterling & Post-ovulatory & 13 \\
& Pre-ovulatory & 16 \\
\hline Slender bittering & Post-ovulatory & 12 \\
& Pre-ovulatory & 15 \\
\hline
\end{tabular}

Each thirty males were tested. Some males did not respond within 10 min.

Table 5. Response of males to pairs of stimulus sources in the $\mathrm{Y}$-maze

\begin{tabular}{cccc}
\hline Species & $\begin{array}{c}\text { Stimulus } \\
\text { source* }\end{array}$ & $\begin{array}{c}\text { No. of } \\
\text { males } \\
\text { responded }\end{array}$ & $\gamma^{2}$-test \\
\hline $\begin{array}{c}\text { Rose } \\
\text { bitterling }\end{array}$ & $\begin{array}{l}\text { Egg washings } \\
\text { Washed eggs }\end{array}$ & 22 & $p<0.01$ \\
& Washed eggs & 7 & $p<0.02$ \\
& Ovary & 19 & \\
\hline Slender & Egg washings & 23 & $p<0.001$ \\
bitterling & Washed eggs & 5 & \\
& Washed eggs & 8 & $p<0.05$ \\
& Ovary & 20 & \\
\hline
\end{tabular}

* See Table 1. Thirty males were tested in each test. Some males did not respond within $10 \mathrm{~min}$.

These results indicate that pheromone is present not in ovulated eggs but in egg washings including genital cavity fluid and in ovaries of post-ovulatory females in both species. Nonexistence of sex pheromone in ovulated eggs was also observed in Plecoglossus altivelis, ${ }^{3)}$ Salmo gairdneri, ${ }^{4)}$ and Misgurnus anguillicaudatus ${ }^{\mathrm{s})}$ by the author.

To see whether or not males of each species are able to discriminate between post-ovulatory females of their own kind and those of the other species, preference tests were carried out. As shown in Table 6, males of each species were able to discriminate post-ovulatory female of their own kind from the other species one without actually
Table 6. Species-specific response of males of rose and slender bitterlings to post-ovulatory female of their own kinds in the Y-maze

\begin{tabular}{|c|c|c|c|}
\hline \multirow{2}{*}{$\begin{array}{l}\text { Post-ovulatory } \\
\text { female }\end{array}$} & \multicolumn{2}{|c|}{$\begin{array}{l}\text { No. of males } \\
\text { responded }\end{array}$} & \multirow{2}{*}{$x^{2}$-test } \\
\hline & Rose & Slender & \\
\hline Rose & 21 & 6 & $p<0.001$ \\
\hline Slender & 5 & 23 & \\
\hline
\end{tabular}

sighting the females. And in the case of using preovulatory females of both species as a pair of stimulus sourses, males of both species did not show species-specific response to the females in the $\mathrm{Y}$-maze. These results indicate that there is species-specificity of female sex pheromone in the two bitterlings. And it is considered that sex pheromone specificity in the two bitterlings is one of several mechanisms of reproductive isolation under natural conditions.

\section{Conclusion}

This study has demonstrated the presence of female sex pheromones of rose bitterling and slender bitterling, which plays respectively some essential roles in the courtship behaviour of each species, and also the species-specificity of the pheromones in the two bitterlings.

\section{Acknowledgement}

The author expresses his gratitude to Prof. H. Tsukahara, Kyushu University, for his guidance.

\section{References}

1) K. Asahina, I. Iwashita, I. Hanyu, and T. HibiYa: Bull. Japan. Soc. Sci. Fish., 46, 299305 (1980).

2) P. R. Wiepkema: Arch. Néerl. Zool., 14, 103199 (1961).

3) H. Honda: Bull. Japan. Soc. Sci. Fish., 45, 1375-1380 (1979).

4) H. Honda: Bull. Japan. Soc. Sci. Fish, 46, 1109-1112 (1980).

5) H. Honda: Bull. Japan. Soc. Sci. Fish., 46, 1223-1225 (1980).

6) M. Nakamura: Cyprinid Fishes of Japan, Research Institute for Natural Resources, Tokyo, 1969 , pp. 307-329.

7) Y. Nagata and K. Nishiyama: Physiol. Ecol. Japan, 17, 85-90 (1976). 